\title{
Bioprospecting of phosphorus solubilizing bacteria from Renuka Lake Ecosystems, Lesser Himalayas
}

\author{
Divjot Kour ${ }^{1}$, Kusam Lata Rana ${ }^{1}$, Neelam Yadav², Ajar Nath Yadav ${ }^{1 *}$ \\ ${ }^{1}$ Department of Biotechnology, Akal College of Agriculture, Eternal University, Baru Sahib, Sirmour, India \\ ${ }^{2}$ Gopi Nath P.G. College, Veer Bahadur Singh Purvanchal University, Ghazipur, India
}

\begin{tabular}{l}
\hline ARTICLE INFO \\
\hline Article history: \\
Received on: April 07, 2019 \\
Accepted on: May 25, 2019 \\
Available online: September 10, 2019 \\
\hline
\end{tabular}

Key words:

Diversity, lesser Himalayas, $P G P$

traits, P-solubilization, Renuka

Lake

\begin{abstract}
In the present study, diversity and plant growth promoting traits of bacteria isolated from Renuka Lake, Himachal Pradesh was investigated. A total of three samples, including sediment (pH-7.3), sub-surface water (pH-8.1), and surface water ( $\mathrm{pH}-8.2$ ), were collected. A total of 65 bacterial isolates were obtained on different growth media. Among 65 isolates 18 isolates were found to be solubilizers of phosphorus. The maximum amount of phosphorus was solubilized by EU-RL $54(7,976 \pm 0.01 \mu \mathrm{g} / \mathrm{l})$ followed by EU-RL 53 (6,322 \pm 0.01 $\mu \mathrm{g} / \mathrm{l})$. Phosphorus solubilizers also possessed other plant growth promoting traits, such as the production of ammonia, hydrogen cyanide, zinc solubilization, production of hydrolytic enzymes. The isolates were identified belonging to different genera Acinetobacter, Bacillus, Enterobacter, Klebsiella, Proteus, Pseudomonas, and Staphylococcus. This is the first report for these plant growth promoting bacteria to solubilize a considerable amount of phosphorus isolated from Ecosystems, Lesser Himalayas.
\end{abstract}

\section{INTRODUCTION}

The earth's surface is mostly covered with water and about $96 \%$ consist of marine ecosystems. Both marine and freshwater environment are rich in biodiversity and important for proper functioning as well as maintaining health of the environment [1]. Furthermore, microbial communities in both water as well as sediment have been shown to make a great contribution to health of the lakes [2]. The ever-present microorganisms are the chief players in cycling of all the elements between sediments, waters, and the atmosphere which is actually known to be key driver of the microbial processes as well as range of natural ecosystems [1]. Many studies have been carried out on lake ecosystems which show that growth and distribution of sediment microbial communities are greatly affected by the availability of carbon sources [1]. Microbial communities, especially in sediment, are chiefly important because of their greater cell density as well

\footnotetext{
*Corresponding Author

Ajar Nath Yadav, Department of Biotechnology, Akal College of Agriculture, Eternal University, Sirmour, India.

E-mail: ajar@eternaluniversity.edu.in
}

as taxonomic diversity and they can respond quickly to their surrounding environmental [3-5].

Renuka Lake is the largest lake in Himachal Pradesh, with a circumference of about $3,214 \mathrm{~m}$. The lake is oval shaped and has water spread of 670 ha [6]. The annual rainfall in this region is estimated to be between 150 and $199.9 \mathrm{~cm} \mathrm{[7].} \mathrm{The} \mathrm{length} \mathrm{and}$ breadth of Renuka Lake is 10.50 and $204 \mathrm{~m}$, respectively, with a maximum depth of $\sim 13 \mathrm{~m}$ and the catchment area $\sim 254.3$ ha. The silt and debris are deposited in the lake all around the catchment of the lake which is leading to ecological deterioration, eutrophication, and habitat degradation [8]. Due to biological richness of Lake, it has been designated as the wetland of national importance by the Wetland Management Committee [8]. The reports on study of Renuka Lake is very scanty and the literature on Renuka Lake available is either on its geochemistry or this lake as newfound residence for migratory birds, or fluctuations in zooplanktons, and ion chemistry [6, 8-10] and studies on its microbial diversity has not been yet done. Thus, besides investigating flora and fauna of Lake Ecosystem, microbial diversity is also of utmost importance. Therefore, this area was chosen for the present study to investigate the microbial communities present in this particular ecosystem and the roles they may contribute in promoting growth of the plants. 


\section{MATERIALS AND METHODS}

\subsection{Sampling, Enumeration, and Isolation of the Bacteria}

The study area was Renuka Lake located in Sirmour district of Himachal Pradesh, $672 \mathrm{~m}$ above the sea level bound by $30^{\circ} 36^{\prime} 30^{\prime} \mathrm{N}$ latitude and $77^{\circ} 27^{\prime} 6^{\prime \prime} \mathrm{E}$ longitude. A total of three samples, including sediment, sub-surface water, and surface water, were collected in sterile polyethene bags and bottles, respectively, and stored at $4{ }^{\circ} \mathrm{C}$ until analysis. The $\mathrm{pH}$ of the samples was also recorded. The culturable bacteria in sediment and water samples were isolated through enrichment using the standard serial dilution plating technique. Different growth media were employed for isolation, such as: Nutrient agar medium, King's B agar, Tryptic soy agar, $\mathrm{R}_{2} \mathrm{~A}$ medium, Ammonium salt agar medium, and Jenson agar [11]. After appearance of the colonies, they were purified by repeated re-streaking on nutrient agar to obtain isolated colonies. Once the pure cultures were obtained, they were further maintained in slants and $25 \%$ glycerol stock at $4{ }^{\circ} \mathrm{C}$ and $-80^{\circ} \mathrm{C}$, respectively.

\subsection{Screening and Identification of P-solubilizing Microbes}

All the isolates obtained were screened qualitatively for solubilization of the phosphorus on Pikovskaya agar using three different insoluble substrates of phosphorus, including rock phosphate, apatite, and tricalcium phosphate [12]. The phosphorus solubilizers were quantitatively assayed for phosphate solubilization by method described by Murphy and Riley [13]. P-solubilizing bacteria were screened for other plant growth promoting attributes using the standard methods. All P-solubilizers were screened for solubilization of potassium, zinc, production of indole-3-acetic acid, ammonia, hydrogen cyanide ( $\mathrm{HCN})$, amylases, cellulases, pectinases, and proteases using standard method as described earlier [14-16]. The isolates were identified on biochemical basis using standard methods. The various tests performed were indole test, methyl red test, Voges-Proskauer test, citrate utilization, fermentation of glucose, sucrose, maltose, and production of catalase and oxidase.

\section{RESULTS}

\subsection{Enumeration and Isolation}

The population of heterotrophic bacteria was enumerated in three samples that were isolated from Renuka Lake in Sirmour district of Himachal Pradesh. A considerable variation was observed in number of colonies isolated on each media used. The maximum isolates were obtained from surface water followed by sediment and sub-surface water. A total number of 98 bacterial isolates were obtained from three samples on different media.

\subsection{Characterization and Identification of P-solubilizing Bacteria}

All strains screened for phosphorus solubilization showed variable results on different insoluble sources of phosphorus used. Out of 98 strains, only 18 strains solubilized phosphorus (Table 1). Phosphorus solubilization was found in the range of $3,440 \pm 0.01 \mu \mathrm{g} / 1$ to $7,976 \pm 0.01 \mu \mathrm{g} / \mathrm{l}$ (Fig. 1). The maximum amount of phosphorus was solubilized by Staphylococcus sp. EU-RL 54 followed by Enterobacter sp. (EU-RL 53) solubilizing $6,322 \pm 0.01 \mu \mathrm{g} / 1$ (Table 1). The downfall in $\mathrm{pH}$ were recorded highest EU-RL 53 (Fig. 2). Screening of P-solubilizers for diverse direct and indirect plant growth promoting attributes; it was found that, 18, and 5 showed the P-solubilizing and zinc solubilizing activity, respectively. The production of

Table 1. Phosphorus solubilizing bacteria from Renuka Lake ecosystems with multifarious plant growth promoting attributes.

\begin{tabular}{|c|c|c|c|c|c|c|c|c|c|c|c|}
\hline \multirow[b]{2}{*}{ Strains } & \multirow[b]{2}{*}{ P-solubilizers } & \multirow[b]{2}{*}{ Source } & \multicolumn{2}{|c|}{ P-solubilization } & \multirow[b]{2}{*}{ Amy } & \multirow[b]{2}{*}{ Pec } & \multirow[b]{2}{*}{ Pro } & \multirow[b]{2}{*}{ Zinc } & \multirow[b]{2}{*}{$\mathrm{HCN}$} & \multirow[b]{2}{*}{$\mathrm{NH}_{3}$} & \multirow[b]{2}{*}{ IAA } \\
\hline & & & Amt $(\mu \mathrm{g} / \mathrm{l})$ & pH & & & & & & & \\
\hline EU-RL 2 & Klebsiella sp. & SD & $3,764 \pm 0.00$ & 5.9 & - & - & - & - & - & - & + \\
\hline EU-RL 8 & Enterobacter sp. & SD & $4,170 \pm 0.01$ & 6.0 & - & - & + & + & - & - & - \\
\hline EU-RL 9 & Pseudomonas sp. & SD & $3,677 \pm 0.01$ & 6.6 & - & - & + & + & - & + & + \\
\hline EU-RL 10 & Proteus sp. & SD & $4,970 \pm 0.01$ & 6.3 & - & - & - & - & - & - & - \\
\hline EU-RL 11 & Proteus sp. & $\mathrm{SD}$ & $3,511 \pm 0.00$ & 6.5 & - & - & - & - & - & - & + \\
\hline EU-RL 25 & Klebsiella sp. & SS & $5,188 \pm 0.00$ & 5.8 & - & - & - & - & + & - & - \\
\hline EU-RL 35 & Proteus sp. & $\mathrm{S}$ & $4,590 \pm 0.01$ & 6.4 & - & - & - & + & + & + & - \\
\hline EU-RL 39 & Enterobacter sp. & $\mathrm{S}$ & $5,023 \pm 0.01$ & 6.8 & - & - & + & + & - & + & + \\
\hline EU-RL 49 & Enterobacter sp. & $\mathrm{S}$ & $4,000 \pm 0.01$ & 6.8 & - & - & + & - & - & - & - \\
\hline EU-RL 51 & Enterobacter sp. & $\mathrm{S}$ & $4,275 \pm 0.01$ & 6.4 & - & - & - & - & - & - & + \\
\hline EU-RL 52 & Enterobacter sp. & $\mathrm{S}$ & $3,566 \pm 0.01$ & 6.6 & - & - & - & - & - & - & - \\
\hline EU-RL 53 & Enterobacter sp. & $\mathrm{S}$ & $6,322 \pm 0.01$ & 6.1 & - & + & - & - & - & - & - \\
\hline EU-RL 54 & Staphylococcus sp. & $\mathrm{S}$ & $7,976 \pm 0.01$ & 6.6 & + & - & - & - & - & - & - \\
\hline EU-RL 56 & Bacillus sp. & $\mathrm{S}$ & $3,440 \pm 0.01$ & 6.8 & - & - & + & + & - & + & - \\
\hline EU-RL 57 & Acinetobacter sp. & $\mathrm{S}$ & $5,511 \pm 0.00$ & 6.7 & - & - & - & - & - & + & - \\
\hline EU-RL 62 & Enterobacter sp. & $\mathrm{S}$ & $5,346 \pm 0.02$ & 6.1 & - & - & + & - & - & + & + \\
\hline EU-RL 63 & Enterobacter sp. & $\mathrm{S}$ & $3,913 \pm 0.03$ & 6.5 & - & - & - & - & - & - & - \\
\hline EU-RL 64 & Enterobacter sp. & $\mathrm{S}$ & $3,511 \pm 0.01$ & 6.8 & - & - & - & - & - & - & - \\
\hline
\end{tabular}


indole-3-acetic acid (IAA), ammonia, and hydrogen cyanide $(\mathrm{HCN})$ was found in 6, 6, 2 isolates, respectively. Amylase activity, pectinase, and protease activity were shown by 1,1 and 6 isolates, respectively. None of the P-solubilizer showed cellulase activity. Among $18 \mathrm{P}$-solubilizers, only six isolates possessed multiple plant growth promoting traits (Table 1). Based on biochemical characterization, the isolates belonged to genera Acinetobacter, Bacillus, Enterobacter, Klebsiella, Proteus, Pseudomonas, and Staphylococcus. Enterobacter sp. was the most abundant species isolated followed by Klebsiella sp. and Proteus sp. (Fig. 3).

\section{DISCUSSION}

Freshwater lakes are extremely biodiverse natural water reservoirs, with many important recreational and landscape qualities [17] though freshwater environments have been studied to a lesser extent than marine ones [18]. In aquatic ecosystems, bacteria play an important role in degradation of the organic matter, assimilation of carbon, nitrogen, and phosphorus which are catalyzed by enzymes produced by microorganisms [19-22]. Furthermore, bioprospecting microbial diversity of freshwater lakes is important as they are an important source of microbes which produce diverse enzymes of agricultural and industrial importance, various bioactive compounds, etc.

Renuka Lake in the Lesser Himalaya, Himachal Pradesh is in a valley which is completely surrounded by mountains. It further comprises of highly crumpled, shattered, crushed, folded, and dislocated rocks consisting of carbonaceous shales-slates often pyrite-ferrous, limestone, quartzites, and boulder beds [10]. There are many high altitude sub-glacial lakes in Indian Himalayas that represent hot spots of microbial biodiversity. Huge diversity of microbes has already been reported from Himalayas [23-25]. Yadav et al. [26] reported diverse culturable psychrophilic and psychrotolerant Bacilli producing various cold active hydrolytic enzymes from Chandratal, Dashair, and Pangong Lake of Indian Himalayas. In the present study, we obtained 18 P-solubilizing bacterial strains from sediment, sub-surface water, and surface water. In our study, Enterobacter sp. was the most dominant P-solubilizer. The maximum diversity of P-solubilizers was obtained from surface water followed by sediments. The major source of dissolved materials in the Renuka Lake has been known to be primarily from the weathering of rocks [10], whereas organic source is the major contributor of relative enrichment of $\mathrm{P}_{2} \mathrm{O}_{5}$ in lake sediments [6], which may have contributed to such diversity from surface water and sediments, respectively. In our study, P-solubilizers included Acinetobacter sp., Bacillus sp., Enterobacter sp., Klebsiella sp., Proteus sp., Pseudomonas sp., and Staphylococcus sp., which could solubilize phosphorus in the range $3,440 \pm 0.01$ to $7,976 \pm 0.01 \mu \mathrm{g} / \mathrm{l}$. The study of Gen-Fu and Xue-Ping [27] characterized phosphorus-releasing bacteria which also included Acinetobacter sp., Bacillus sp., Enterobacter sp., and Staphylococcus sp. from a small eutrophic shallow lake, Eastern China, and amount of phosphorus released was 50 $\mu \mathrm{g} / \mathrm{ml}$ by inorganic phosphorus solubilizing bacteria whereas organic phosphorus-mineralizing bacteria released less than 2 $\mu \mathrm{g} / \mathrm{ml}$ water-soluble inorganic phosphorus every day. Qian, et al. [28] characterized phosphorus solubilizing bacteria, including Acinetobacter sp., Burkholderia sp., Citrobacter sp., Cupriavidus

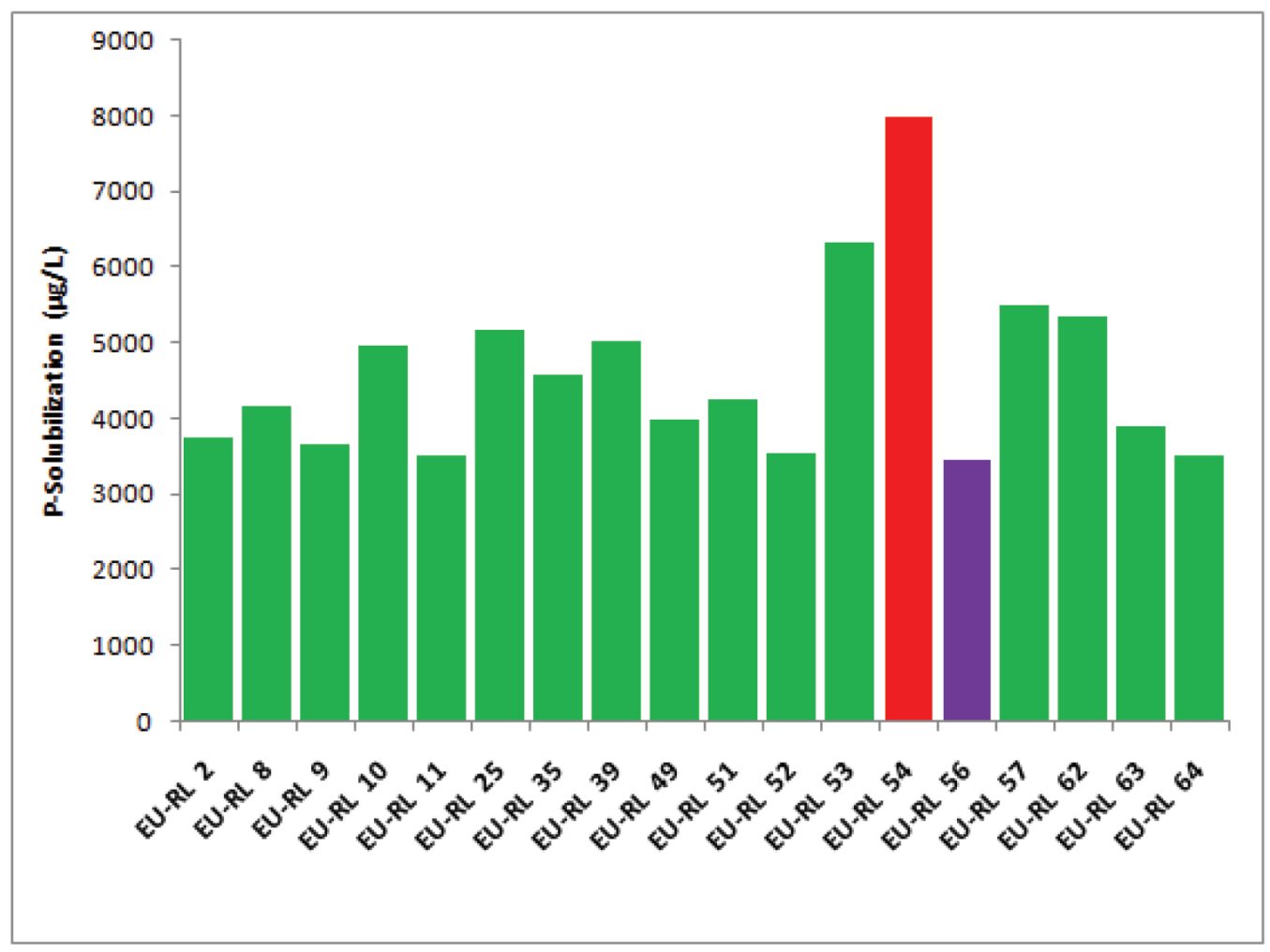

Figure 1: Relative distribution of P-solubilizing capability exhibited by bacteria isolated from Renuka Lake ecosystems, Lesser Himalayas. 


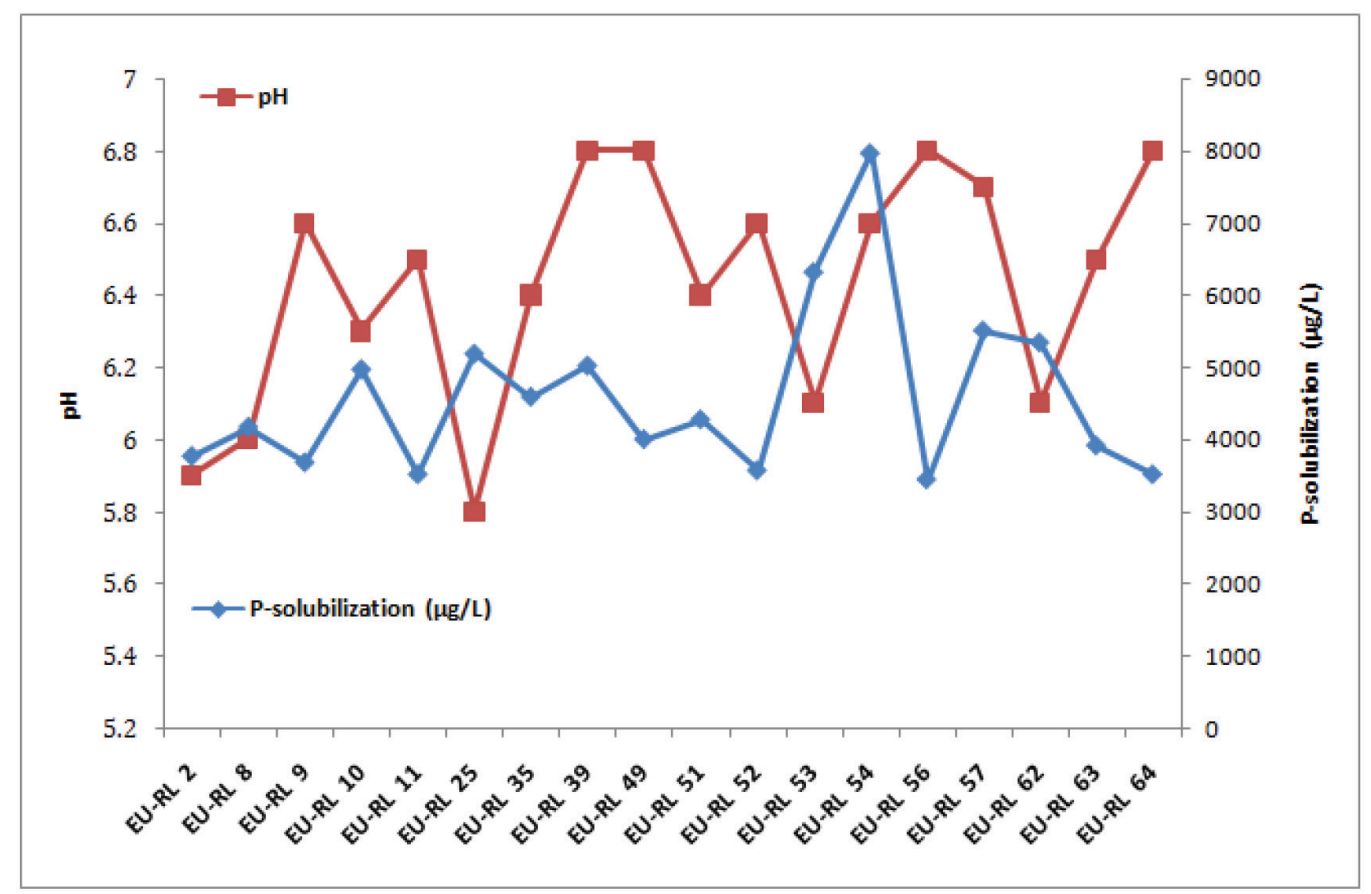

Figure 2: P-solubilization and downfall in $\mathrm{pH}$ by bacteria isolated from Renuka Lake, Lesser Himalayas.

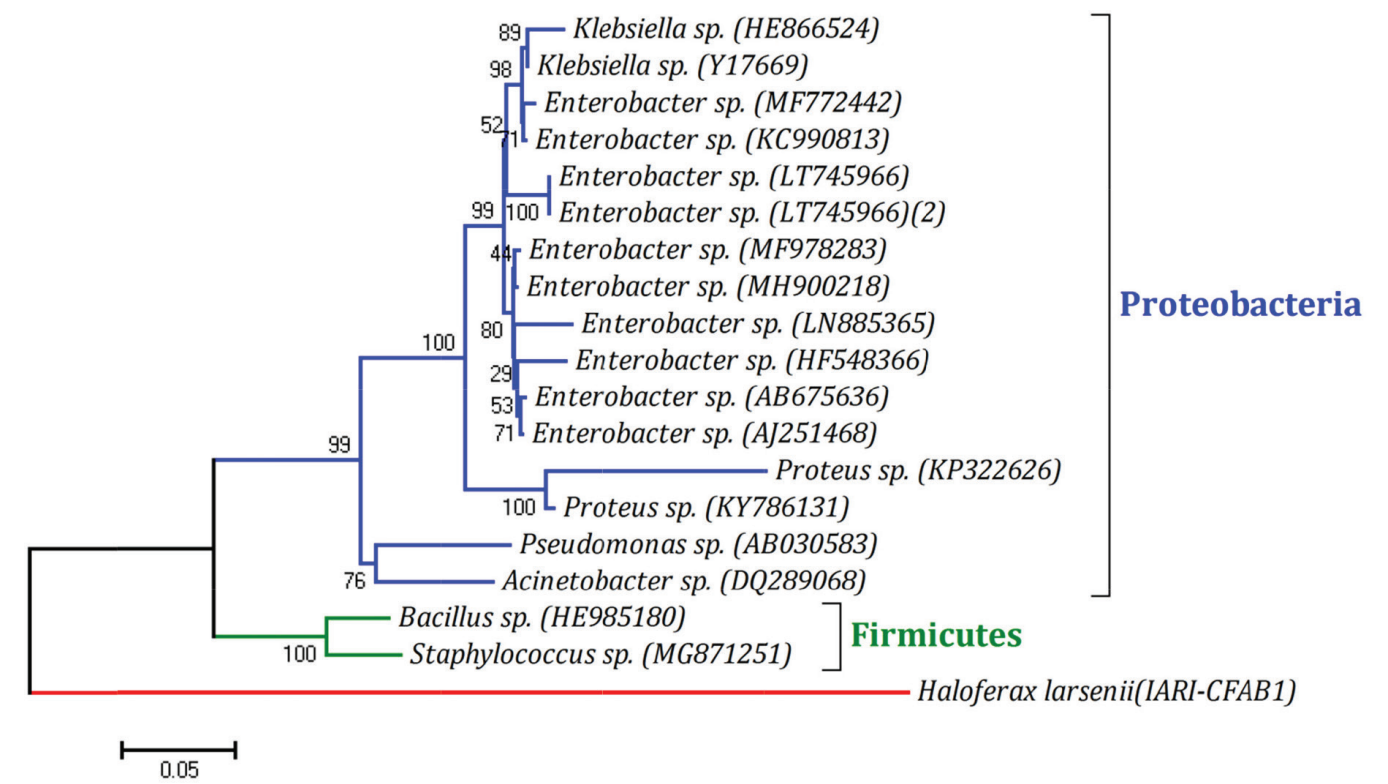

Figure 3: Phylogenetic tree showed the relationship among 18 P-solubilizing bacteria isolated from Renuka Lake, Lesser Himalayas. The sequence alignment was performed using the CLUSTAL W program and trees were constructed using Neighbor Joining (NJ) with algorithm using MEGA4 software.

sp., Enterobacter sp., Pantoea sp., and Pseudomonas sp. from sediments from a Shallow Eutrophic Lake and a wetland. The most efficient inorganic phosphorus solubilizing bacteria strain could accumulate over $170 \mathrm{mg} / \mathrm{l}^{-1}$ orthophosphate, while the equivalent organic phosphorus-mineralizing bacteria liberated less than $4 \mathrm{mg} / \mathrm{l}^{-1}$ orthophosphate in liquid culture. Maitra et al. [29] isolated Bacillus, Brevibacillus, Enterobacter, Agrobacterium, Pseudomonas, Acinetobacter, Microbacterium, Curtobacterium, Stenotrophomonas, and Novosphingobium as phosphorus solubilizers releasing 6.3-68.8 $\mathrm{mg} \mathrm{P} / \mathrm{L}$ from Oxbow Lakes of West Bengal, India. Li et al. [30] reported a novel species of phosphatesolubilizing bacterium from Sanchahu Reservoir which is the second biggest freshwater lake in China.

The 18 P-solubilizers were further screened for diverse direct and indirect plant growth promoting attributes. The six P-solubilizers possessed multifarious plant growth promoting attributes. Among these, six P-solubilizers, Enterobacter sp. was the most dominant 
one showing the production of proteases, ammonia, IAA, and solubilization of zinc followed by Pseudomonas sp. (EU-RL 9) which also possessed same attributes. Proteus sp. (EU-RL 35) and Bacillus sp. (EU-RL 56) also solubilized zinc and produced ammonia, whereas HCN production was shown by strain EU-RL 35 and protease production by EU-RL 56. Among 6 P-solubilizers with multiple plant growth promoting attributes, five solubilized zinc which may be attributed to fact that the lake has high content of zinc [6]. Another common trait found among these bacterial strains was production of ammonia and $\mathrm{HCN}$ which is important trait against phytopathogens. Thus, these bacterial strains with plant growth promoting attributes may have potential applications in agriculture to be used as biofertilizers mainly for the acquisition of unavailable nutrients and as biocontrol agents. To the best of our knowledge, this is the first report of plant growth promoting bacteria from Renuka Lake.

\section{ACKNOWLEDGMENTS}

The authors are grateful to the Department of Biotechnology, Akal College of Agriculture, Eternal University, Baru Sahib and Department of Environment, Science and Technology, Shimla, HP funded project "Development of microbial consortium as bioinoculants for drought and low temperature growing crops for organic farming in Himachal Pradesh" for providing the facilities and financial support, to undertake the investigations.

\section{CONFLICT OF INTEREST}

The authors declared that they have no conflicts of interest.

\section{REFERENCES}

1. Raina V, Panda AN, Mishra SR, Nayak T, Suar M. Microbial biodiversity study of a Brackish water ecosystem in Eastern India: the Chilika Lake. In: Das S, Dash HR (eds.) Microbial diversity in the genomic era. Academic Press, Cambridge, MA, pp 47-63, 2019; doi:https://doi.org/10.1016/B978-0-12-814849-5.00004-6

2. Kumar A, Ng DH, Wu Y, Cao B. Microbial community composition and putative biogeochemical functions in the sediment and water of tropical granite quarry lakes. Microbial Ecol 2019;77(1):1-11.

3. Jørgensen BB, Boetius A. Feast and famine-microbial life in the deep-sea bed. Nat Rev Microbiol 2007;5(10):770.

4. Lozupone CA, Knight R. Global patterns in bacterial diversity. Proc Natl Acad Sci 2007;104(27):11436-40.

5. Gibbons SM, Jones E, Bearquiver A, Blackwolf F, Roundstone W, Scott N, et al. Human and environmental impacts on river sediment microbial communities. PLoS One 2014;9(5):e97435.

6. Das BK, Kaur P. Geochemistry of Renuka Lake and wetland sediments, Lesser Himalaya (India): implications for source-area weathering, provenance, and tectonic setting. Environ Geol 2008;54(1):147-63.

7. Joshi KL. Geography of Himachal Pradesh. National Book Trust, New Delhi, India, 1984.

8. Mohan L, Sharma R, Tak P. Renuka wetland: a newfound abode for migratory birds in Himachal Pradesh. Indian Forester 2005;131(2):163-9.

9. Chauhan R. Seasonal fluctuations of zooplankton in Renuka lake, Himachal Pradesh. Uttar Pradesh J Zool 1993:17-20.

10. Das BK, Kaur P. Major ion chemistry of Renuka lake and weathering processes, Sirmaur district, Himachal Pradesh, India. Environ Geol 2001;40(7):908-17.

11. Verma P, Yadav A, Kazy S, Saxena A, Suman A. Elucidating the diversity and plant growth promoting attributes of wheat (Triticum aestivum) associated acidotolerant bacteria from southern hills zone of India. Natl J Life Sci 2013;10(2):219-26.

12. Yadav AN, Sharma D, Gulati S, Singh S, Kaushik R, Dey R, Pal KK, Saxena AK. Haloarchaea endowed with phosphorus solubilization attribute implicated in phosphorus cycle. Sci Rep 2015;5(12293).

13. Murphy J, Riley JP. A modified single solution method for the determination of phosphate in natural waters. Anal Chim Acta 1962;27:31-6.

14. Yadav AN, Sachan SG, Verma P, Kaushik R, Saxena AK. Cold active hydrolytic enzymes production by psychrotrophic Bacilli isolated from three sub-glacial lakes of NW Indian Himalayas. J Basic Microbiol 2016;56:294-307.

15. Yadav AN, Sachan SG, Verma P, Saxena AK. Bioprospecting of plant growth promoting psychrotrophic Bacilli from cold desert of north western Indian Himalayas. Indian J Exp Biol 2016;54(2):142-50.

16. Yadav AN, Sachan SG, Verma P, Tyagi SP, Kaushik R, Saxena AK. Culturable diversity and functional annotation of psychrotrophic bacteria from cold desert of Leh Ladakh (India). World J Microbiol Biotechnol 2015;31(1):95-108.

17. Ávila MP, Staehr PA, Barbosa FA, Chartone-Souza E, Nascimento A. Seasonality of freshwater bacterioplankton diversity in two tropical shallow lakes from the Brazilian Atlantic Forest. FEMS Microbiol Ecol 2017;93(1).

18. Debroas D, Humbert JF, Enault F, Bronner G, Faubladier M, Cornillot E. Metagenomic approach studying the taxonomic and functional diversity of the bacterial community in a mesotrophic lake (Lac du Bourget-France). Environ Microbiol 2009;11(9):2412-24.

19. Frossard A. Microbial dynamics during stream ecosystem succession: community structure and enzyme activities. ETH Zurich, Zurich, Switzerland, 2011.

20. Yuan H, An S, Liu E, Pan W, Zhu Z. Fractionation and bioavailability of phosphorus in sediments of Huaihe River, China. J Soil Water Conserv 2015;70(5):313-21

21. Fabian J, Zlatanovic S, Mutz M, Premke K. Fungal-bacterial dynamics and their contribution to terrigenous carbon turnover in relation to organic matter quality. ISME J 2017; 11(2):415.

22. Larrea-Murrell JA, Rojas-Badia MM, García-Soto I, Romeu-Alvarez B, Bacchetti T, Gillis A, Boltes-Espinola AK, Heydrich-Perez M, Lugo-Moya D, Mahillon J. Diversity and enzymatic potentialities of Bacillus $s p$. strains isolated from a polluted freshwater ecosystem in Cuba. World J Microbiol Biotechnol 2018;34(2):28.

23. Chaturvedi P, Prabahar V, Manorama R, Pindi PK, Bhadra B, Begum Z, Shivaji S. Exiguobacterium soli sp. nov., a psychrophilic bacterium from the McMurdo Dry Valleys, Antarctica. Int J Syst Evol Microbiol 2008;58(10):2447-53.

24. Kishore KH, Begum Z, Pathan AAK, Shivaji S. Paenibacillus glacialis sp. nov., isolated from the Kafni glacier of the Himalayas, India. Int J Systematic Evol Microbiol 2010;60(8):1909-13.

25. Bisht SC, Mishra PK, Joshi GK. Genetic and functional diversity among root-associated psychrotrophic Pseudomonad's isolated from the Himalayan plants. Arch Microbiol 2013;195(9):605-15.

26. Yadav AN, Sachan SG, Verma P, Kaushik R, Saxena AK. Cold active hydrolytic enzymes production by psychrotrophic Bacilli isolated from three sub-glacial lakes of NW Indian Himalayas. J Basic Microbiol 2016;56(3):294-307.

27. Gen-Fu W, Xue-Ping Z. Characterization of phosphorus-releasing bacteria in a small eutrophic shallow lake, Eastern China. Water Res 2005;39(19):4623-32.

28. Qian Y, Shi J, Chen Y, Lou L, Cui X, Cao R, Li P, Tang J. Characterization of phosphate solubilizing bacteria in sediments from a shallow eutrophic lake and a wetland: isolation, molecular identification and phosphorus release ability determination. Molecules 2010;15(11):8518-33.

29. Maitra N, Bandopadhyay C, Samanta S, Sarkar K, Sharma AP, Manna SK. Isolation, identification and efficacy of inorganic phosphate- 
solubilizing bacteria from Oxbow Lakes of West Bengal, India. Geomicrobiol J 2015;32(8):751-8.

30. Li Y, Ai M-J, Sun Y, Zhang Y-Q, Zhang J-Q. Spirosoma lacussanchae sp. nov., a phosphate-solubilizing bacterium isolated from a freshwater reservoir. Int J Systematic Evolutionary Microbiol 2017;67(9): 3144-9.
How to cite this article:

Kour D, Rana KL, Yadav N, Yadav AN. Bioprospecting of phosphorus solubilizing bacteria from Renuka Lake Ecosystems, Lesser Himalayas. J Appl Biol Biotech 2019;7(05):1-6. 